\title{
Sustainable Hydraulic Barrier Design Technologies for Effective Infrastructure Engineering
}

\author{
Devapriya Chitral Wijeyesekera ${ }^{1, *}$, Eric Wooi Kee Loh $^{2}$ and Alvin John Lim Meng Siang ${ }^{3}$ \\ ${ }^{1,3}$ Faculty of Civil \& Environmental Engineering, Universiti Tun Hussein Onn Malaysia, Johor, \\ Malaysia \\ ${ }^{2}$ Faculty of Built Environment, Linton University College, Negeri Sembilan, Malaysia
}

\begin{abstract}
Migration of liquids lead to embarrassing post construction scenarios such as that of leaks from roofs, potable water leaking from water tanks/ reservoirs, rising damp in walls with groundwater seeping into basement structures, leakage of water from ornamental lakes and ponds or leachate leakage into the environment from MSW landfill sites. Such failures demand immediate and expensive maintenance. A stringent control on structural and waterproof stability is deemed necessary for long term service life of structures and in particular underground and near surface structures. On a micro scale and over a longer time scale, the phenomenon of rising dampness occurs in older buildings with the groundwater rising up through walls, floors and masonry via capillary action. Even slower rates of contaminant fluid migration occur through landfill base liners. In this paper a variety of hydraulic barrier technologies is critically discussed against a backdrop of relevant case studies. The choice of an appropriate hydraulic barrier technology for a given scenario will depend also on the sustainability, financial affordability and subjective aesthetics.
\end{abstract}

\section{Introduction}

World Health Organisation, [1] defines moisture migration problem as "any visible, measurable or perceived outcome caused by excess moisture presence, indoor climate problems or problems of durability in building assemblies caused by various scenarios of water leaks". Impermeable barriers significantly impede such undesirable migration of fluids in a variety of sectors in infrastructure engineering. Water leaks through inherent weaknesses arising within the otherwise integral nature of pipes and roofs are embarrassingly visible effects causing constant concerns which are exasperated during heavy rainfall or excessive water pressure. On the other hand, a wet leaking basement or a poorly engineered landfill may with time manifest the undesirable consequences of mould growth / smell of dampness and pollution of the ground water regime respectively. Resource intensive and time consuming underground constructions demand a sustainable and long term service life. Furthermore, essential urban infrastructure such as the London

* Corresponding author: dcwijey@gmail.com 
or Paris Metro is loathed to become out of service even temporarily be it even for routine maintenance and repair [2]. Increase in acidity of the environment in vicinity of tunnel (decreasing $\mathrm{pH}$ ) increasingly corrode metal and concrete in underground structures, and also generate increasing amounts of soluble aluminium and iron conditions in the soil [3]. Adverse ground conditions such as old landfill sites require checks not only on water migration but also the ingress of noxious landfill gases [4]. Building and Construction Authority [5] reported that the weakest links in ensuring water tightness are in the precast joints; joints between precast elements themselves and also precast element joints with other fittings [6]. Table 1 illustrates the wide variety of documented standard hydraulic barrier technologies [7]. The sustainability and efficacy of the barrier technology/ product is dependent on the appropriateness for the onsite climate and the workmanship.

Table 1. Hydraulic Barrier Types (modified [7])

\begin{tabular}{|l|l|l|}
\hline Type of barrier & Description & Application \\
\hline $\begin{array}{l}\text { Bonded sheet } \\
\text { membranes }\end{array}$ & $\begin{array}{l}\text { Bitumen-based, sheet membranes can be either: } \\
\text { b) Cold-applied (self-adhesive); or } \\
\text { Hot applied ("torch-on" or bonded } \\
\text { using a hot melt bitumen adhesive) }\end{array}$ & $\begin{array}{l}\text { Can be applied externally } \\
\text { or sandwiched. }\end{array}$ \\
\hline $\begin{array}{l}\text { Composite sheet membranes } \\
\text { BS 743: 1970, Class A; or BS 8747 }\end{array}$ & $\begin{array}{l}\text { There are many types of liquid applied } \\
\text { membranes } \\
\text { systems. }\end{array}$ & $\begin{array}{l}\text { Can be applied externally } \\
\text { or sandwiched. }\end{array}$ \\
\hline $\begin{array}{l}\text { Geosynthetic } \\
\text { (bentonite) clay } \\
\text { liners }\end{array}$ & $\begin{array}{l}\text { These comprise of bentonite with a single or } \\
\text { dual 'carrier' material, typically of geotextile or } \\
\text { high-density polyethylene. } \\
\text { There are two principal forms: dry granulated / } \\
\text { powdered bentonite or pre-hydrated bentonite. }\end{array}$ & $\begin{array}{l}\text { Can be applied externally } \\
\text { or sandwiched. }\end{array}$ \\
\hline $\begin{array}{l}\text { Mastic asphalt } \\
\text { membranes }\end{array}$ & $\begin{array}{l}\text { These are applied in three coats as a hot liquid. } \\
\text { BS EN12970 }\end{array}$ & $\begin{array}{l}\text { Can be applied externally } \\
\text { or sandwiched. }\end{array}$ \\
\hline $\begin{array}{l}\text { Cementitious } \\
\text { Crystallization } \\
\text { slurries and } \\
\text { powders }\end{array}$ & $\begin{array}{l}\text { These are applied as coatings to surfaces of } \\
\text { concrete walls and slabs or a solution or powder } \\
\text { added to concrete. }\end{array}$ & $\begin{array}{l}\text { Can be applied internally } \\
\text { or externally. }\end{array}$ \\
\hline $\begin{array}{l}\text { Cementitious } \\
\text { multi-coat } \\
\text { renders, toppings } \\
\text { and coatings }\end{array}$ & $\begin{array}{l}\text { These are generally applied in multi-coats or } \\
\text { slurries and are resistant to liquid water but } \\
\text { allow some water vapour penetration. }\end{array}$ & $\begin{array}{l}\text { Can be applied internally } \\
\text { or externally. }\end{array}$ \\
\hline
\end{tabular}

\section{Gravity Induced Water Migration}

Thatched roofs (Fig. 1) are greatly admired architectural splendour and an outcome of past 'Biotechnology'. Water migrations in any leaking roof is gravity induced and result from; leaking capping / ridging (cracking of the cement mix; absence of expansion joints, punctured plastic sheeting), leaking valley sections (premature rotting from moisture concentrations and delayed drying), Wind damaged corners (thin weakly compacted thatching unable to restrain lifting by wind), Inadequately compacted thatch (require 35-50 $\mathrm{kg} / / \mathrm{m}^{3}$ density to reduce fire risk, Animal or bird damage ( deter the animals having access to the roof) and alike. 


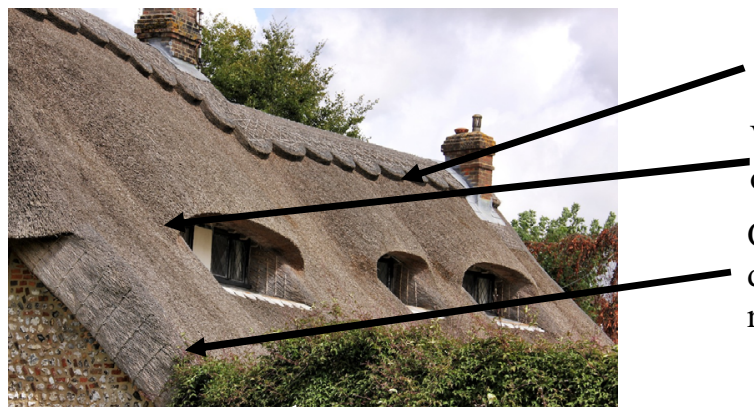

Fig. 1. Thatched Roofs - (modified [8])

Capping / Ridging

Valley sections - intersection of two or more roof slopes Corners - subject to wind / storm damage - need carefully hex net reinforced thatching

Discourage easy access to the roof by animals

Commercial and residential buildings are prone to face problems associated with water leakage; defective roofs, wet area water permeation (balconies, toilets, kitchens), internal / embedded pipe bursts or leaks from the pipe joints, and external wall infiltration by rainwater. Such undesirable leaks cannot be hidden for long as they manifest themselves; damaged ceilings /floors, dampened ceilings / walls and mould or fungi growth (Fig. 2).
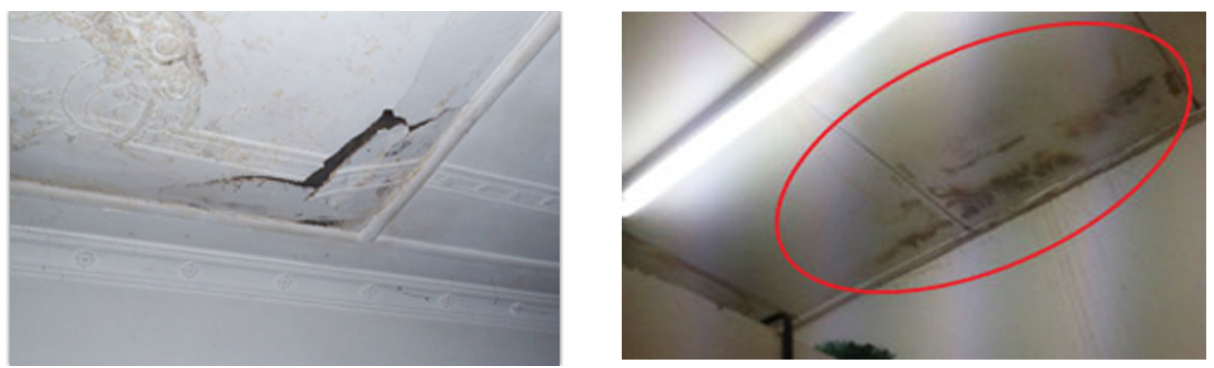

Fig. 2. Damaged Ceilings and Mould growth with Leaking Roofs - (modified [9])

Several generic types of waterproofing materials used for protecting concrete structures, such as cement-based, epoxy resin, polyurethane resin, acrylic resin, and silane /siloxane. These vary in terms of their price, durability performance, and method of application. The environment and the climatic conditions have a pronounced effect on the life span of such sealants. An initial comparative study of the efficiency of commercial waterproofing materials for roofs in Malaysia and UK was carried out by Roslan Talib et al. [10]. Summary of their research on waterproofing products are presented in Table 2.

\section{Geosynthetic Clay Liners as Contaminant Barriers}

Imposition of stringent environmental regulations of not contaminating previously untouched 'green-field' sites or removing the legacy of previous human occupations in the so called "brown-field" or derelict lands necessitate the adoption of sustainable contaminant barriers. A 1994 geo environmental case study investigation observed that a granulated bentonite Geosynthetic Clay Liner (granular/powder type GCL) "failed" in preventing the ingress of water into an old Victorian London vault. This construction was during the time of pioneering and emerging development of GCLs. An internal visual inspection of the vault roof showed that the GCL was not performing as a hydraulic barrier. Model tests were planned and carried out on the GCL in a tank apparatus developed to mimic the site conditions. Together with the support lip, sodium bentonite paste was extruded to give a receptive waterproof medium for the framed GCL. The GCL was attached to the frame using rivets to simulate a membrane of infinite area. A drainage layer of washed gravel was 
placed directly onto the membrane and the permeant was connected via pipes to a drainage trough. The base was given a 10-degree pitch to ensure positive drainage, with the gravel. thickness decreasing from $100 \mathrm{~mm}$ down to $50 \mathrm{~mm}$ to give a horizontal top surface.

Table 2. List of Waterproofing products [modified 9]

\begin{tabular}{|c|c|c|c|}
\hline Company details & $\begin{array}{l}\text { Year of Establishment } \\
\text { \& Logo }\end{array}$ & Product application & Climate \\
\hline $\begin{array}{l}\text { Bostik } \\
\text { Paris, France } \\
\text { Worldwide market }\end{array}$ & Bostirs & Sealants and adhesive & $\begin{array}{l}\text { Temperate \& } \\
\text { Tropical all } \\
\text { year }\end{array}$ \\
\hline $\begin{array}{l}\text { Soprema, Straspourg, } \\
\text { France } \\
\text { Worldwide market }\end{array}$ & $1908-$ & Liquid membrane & $\begin{array}{l}\text { Temperate \& } \\
\text { Tropical all } \\
\text { year }\end{array}$ \\
\hline $\begin{array}{l}\text { Sika AG Group } \\
\text { Baar, Switzerland } \\
\text { Worldwide market }\end{array}$ & 1910 & $\begin{array}{l}\text { Epoxy coating (Outdoor); } \\
\text { Cementitious (indoor wet } \\
\text { areas / outdoor use to be } \\
\text { rendered on top) }\end{array}$ & $\begin{array}{l}\text { Temperate \& } \\
\text { Tropical all } \\
\text { year }\end{array}$ \\
\hline $\begin{array}{l}\text { Axter } \\
\text { Paris, France } \\
\text { Worldwide market }\end{array}$ & 1922- & $\begin{array}{l}\text { Torch applied membrane: } \\
\text { anti root with bituminous } \\
\text { membrane }\end{array}$ & \begin{tabular}{|l} 
Temperate \& \\
Tropical all \\
year \\
\end{tabular} \\
\hline $\begin{array}{l}\text { Fosroc Ltd. } \\
\text { London, UK and Dubai } \\
\text { UAE. Worldwide market }\end{array}$ & 1940 & $\begin{array}{l}\text { Construction sealants and, } \\
\text { Wet areas cementitious }\end{array}$ & $\begin{array}{l}\text { Temperate \& } \\
\text { Tropical all } \\
\text { year }\end{array}$ \\
\hline $\begin{array}{l}\text { GE Sealants } \\
\text { Hountsville, NC, USA } \\
\text { Worldwide market } \\
\end{array}$ & $1940-$ & $\begin{array}{l}\text { Construction sealants } \\
\text { Silicone sealants }\end{array}$ & $\begin{array}{l}\text { Temperate \& } \\
\text { Tropical all } \\
\text { year } \\
\end{array}$ \\
\hline $\begin{array}{l}\text { Shell Malaysia } \\
\text { Kuala Lumpur, Malaysia } \\
\text { Malaysia market only }\end{array}$ & 1964- & $\begin{array}{l}\text { Shell Flintkote for internal } \\
\text { wet area waterproofing as } \\
\text { well as for flat concrete } \\
\text { roof and metal roofs }\end{array}$ & $\begin{array}{l}\text { Tropical } \\
\text { climate }\end{array}$ \\
\hline $\begin{array}{l}\text { Atlas Industry Sdn Bhd } \\
\text { (Taiko Group) Selangor, } \\
\text { Malaysia market only }\end{array}$ & $1968-$ & $\begin{array}{l}\text { Coating primer. Modified } \\
\text { bituminous compound } \\
\text { emulsions. Synthetic resin. }\end{array}$ & \begin{tabular}{|l|} 
Tropical \\
climate
\end{tabular} \\
\hline $\begin{array}{l}\text { Bitumat } \\
\text { Dammam, KSA } \\
\text { Mid-East, Africa, Asia, } \\
\text { America }\end{array}$ & $1975-$ & Bitumen's torch membrane & $\begin{array}{l}\text { Tropical } \\
\text { climate }\end{array}$ \\
\hline $\begin{array}{l}\text { Polycell Sdn Bhd (Tyga Co) } \\
\text { Selangor, Malaysia } \\
\text { Malaysia market only }\end{array}$ & $1980-$ & Foam grout & $\begin{array}{l}\text { Tropical } \\
\text { Climate }\end{array}$ \\
\hline $\begin{array}{l}\text { Axel Chemie Sdn Bhd } \\
\text { Kuala Lumpur, Malaysia } \\
\text { Malaysia market only }\end{array}$ & 198 & $\begin{array}{l}\text { Roof coating for metal, } \\
\text { clay and concrete flat roof }\end{array}$ & $\begin{array}{l}\text { Tropical } \\
\text { climate }\end{array}$ \\
\hline $\begin{array}{l}\text { Quicseal Pte Ltd } \\
\text { Singapore } \\
\text { Malaysia China, } \\
\text { Phillipines, South Korea }\end{array}$ & $1988-$ & $\begin{array}{l}\text { Liquid based } \\
\text { waterproofing system. } \\
\text { Silicone sealant }\end{array}$ & $\begin{array}{l}\text { Temperate \& } \\
\text { Tropical all } \\
\text { year }\end{array}$ \\
\hline $\begin{array}{l}\text { ESTOP Sdn Bhd } \\
\text { Shah Alam, Selangor } \\
\text { Malaysia, Phillipines,S } \\
\text { Korea Indonesia, Singapore, } \\
\text { Hong Kong, China } \\
\end{array}$ & $1990-$ & $\begin{array}{l}\text { Waterproofing system, } \\
\text { coating, water stop, joint } \\
\text { filler, sealants, concrete } \\
\text { repair and grout }\end{array}$ & $\begin{array}{l}\text { Temperate \& } \\
\text { Tropical all } \\
\text { year }\end{array}$ \\
\hline $\begin{array}{l}\text { Bina Paint Marketing Sdn } \\
\text { Bhd Selangor Malaysia } \\
\text { Malaysia market only }\end{array}$ & $\begin{array}{l}1992- \\
\text { BINAPA }\end{array}$ & $\begin{array}{l}\text { Elastometric } \\
\text { waterproofing coating }\end{array}$ & \begin{tabular}{|l|} 
Tropical \\
climate
\end{tabular} \\
\hline
\end{tabular}


Approximately 20 litres of water was showered onto the rye grass turf over a period of 5 days, in an attempt to simulate average rainfall. The water that penetrated the membrane upon initial wetting was 0.7 litres. After the test period of 8 months, the model was dismantled. The GCL's upper geotextile was then carefully cut away to expose the swollen bentonite (Fig. 3). X-ray diffraction analysis revealed that the bentonite was still a $\mathrm{Na}^{+}$rich montmorillonite with a moisture content of $27.7 \%$. The hydraulic conductivity remained in the same order of magnitude of $1 \times 10^{-11} \mathrm{~m} / \mathrm{s}$ as was being achieved with standard hydraulic conductivity tests. There being no visual desiccation cracks or variation in $\mathrm{X}$ ray diffraction studies, assured that the GCL ought to have acted as an efficient barrier system.

However there was onsite evidence that the soil had been fertilised with an N-P-K (8-816) fertiliser, which consisted of calcium ions. Samples of the fertiliser were obtained and the GCL retested with a quantity of $500 \mathrm{ml}$ of N-P-K added to a $600 \times 600 \mathrm{~mm}$ sample in the field simulation test apparatus. Water was again showered and the simulation repeated for the next 5 days to correspond to the rainfall of this time period. After five days the new GCL sample was exposed and is was clear from a visual inspection that the material had failed as a barrier system (Fig.4). The formation of a distinct crack pattern was clearly visible on the membrane. The material was then sampled for moisture content and x-ray diffraction. It was found that the moisture content had remained at $27.7 \%$ but the x-ray diffraction analysis revealed that the clay had undergone cation exchange resulting in a conversion to a $\mathrm{Ca}^{2+}$ (calcium) rich montmorillonite. Hence, $\mathrm{X}$ ray diffraction studies confirmed that the fertiliser with calcium ions caused the failure of the GCL in this case.

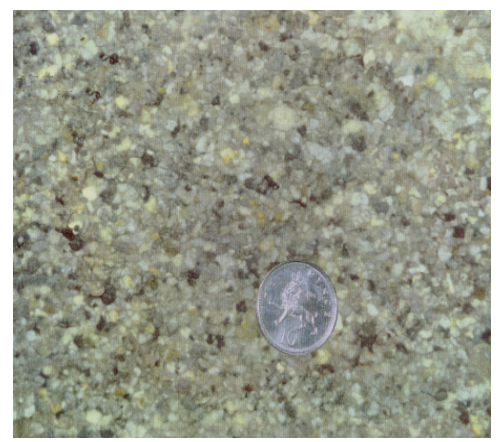

Fig. 3. Exposed bentonite showing swelling

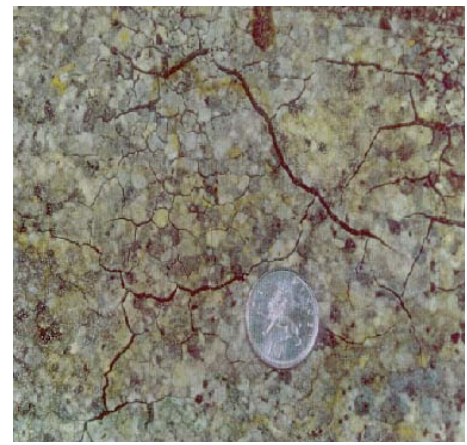

Fig. 4. Formation of cracks through cation exchange

\subsection{Long Term Testing of Geosynthetic Clay Liners}

Bentonite-based liners have gained acceptance for use as hydraulic barriers in industrial and municipal waste containment and sealing applications $\left(\mathrm{k}<10^{-11} \mathrm{~m} / \mathrm{s}\right)$. The current environmental monitoring practice adopted for measuring hydraulic conductivities are short-term laboratory tests with a modest testing routine. These fail to reflect the long-term dynamic changes in hydraulic conductivity performance of the bentonite in them. Interaction of bentonite with high electrolyte concentrations of high cation valence present in hostile geo-environment significantly increases the hydraulic conductivity of the bentonite through the reduction in the double layer thickness consequent to cation exchange. This defeats the prime objective of the field application of contaminant barrier as a sealing application intended to be sustainable perpetually or at least for 100 years.

A long term assessment was carried out on a polymer hydrated and vacuum extruded bentonite clay mat with non-standard liquids in order to examine the variation in hydraulic conductivity over time. This testing approach superseded the current short-term 
conventional laboratory testing and focused specifically on the long term hydraulic performance of GCLs when subjected to permeation that are representative of actual and commonly met hostile geo-environment conditions (Fig. 5). The overburden stress on the specimen was made up of a $300 \mathrm{~mm}$ thick selected material appropriate to the respective field condition. Each specimen was placed between two porous plates and a free flow condition with a hydraulic head of $25 \mathrm{kPa}$ maintained at the base and applied to the leachate at the testing times. Fig. 6 illustrates the variation in hydraulic conductivity (observed via a modified constant head test) during the reporting period of ten years. There is evidence of a marginal increase in hydraulic conductivity with time, but it is not detrimental to the performance criteria, even after 10 years' time.

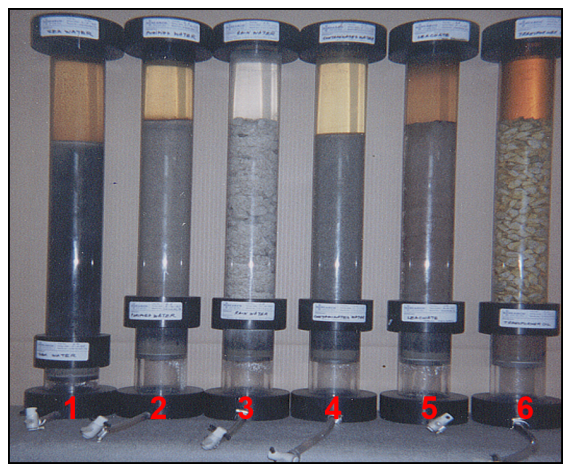

Fig. 5. Long-term Test Cells of Prehydrated GCL when permeated with non-standard liquids. (1) Mine Water, (2) Contaminated Water, (3) Rain water with Limestone Chip, (4) Sea Water, (5) Synthetic Leachate, (6) Transformer Oil

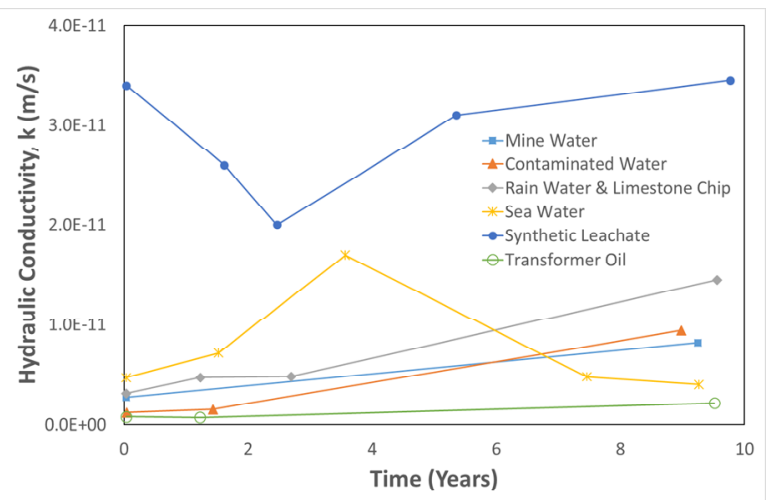

Fig. 6. Long term hydraulic conductivity results for Prehydrated GCL when permeated with nonstandard liquids

\section{Corrosion Control of Concrete Structures}

Results of Al-Dulaijan et al. [11] showed that the adhesion of all the epoxy-resin- based coatings, to the concrete substrate, was better than that of the acrylic- resin-based surface coatings. The adhesion values of the resin-based surface coatings ranged from 1.25 to 2.03 $\mathrm{MPa}$. Their extended investigations [12] on the performance of four cement-based surface coatings reported that the adhesion of the tested coatings ranged between 1.10 and 1.60 $\mathrm{MPa}$. Effective waterproofing parameters include porosity, pore volume, permeability / hydraulic conductivity and more. The chloride permeability [13] was also evaluated and the 
values ranged between 552 and 1113 C. Pfeiffer and Scali [14] indicated that epoxies, methyl methacrylates, urethanes and silane provide an excellent barrier against the ingress of chloride ions into concrete cubes after 21 days of continuous immersion in $15 \% \mathrm{NaCl}$ solution. They investigated the effect of concrete surface treatments on several properties of concrete including water absorption, initiation of reinforcement corrosion and cracking which resulted in the reduction in water absorption [15]. Precast Concrete (PC) framing systems fit snugly within the Industrialised Building System (IBS). Its full adoption is limited by water migration problems, where leakages occur through the joints of the precast elements. Hence, Lachimpandy et al. [16] proposed the alternative adoption of a mixed/ hybrid of In-situ Reinforced Concrete (IRC) and PC as an amalgamation of the conventional construction and IBS. In such instances, reliable solutions of sustainable moisture barrier technology in wet areas such as toilets will help reduce or eliminate use of IRC method of construction. PC joints are sealed to prevent ingress of water and air into building. PC joints can be sealed as open-drained, face-sealed and compression-sealed [17]. Of all the many types of sealant materials available, polyurethane (single and multicomponent) and single component silicone are two (2) most commonly used sealant materials for sealing joints between PC components [18]. Sealant does not bond properly on wet and porous surfaces like concrete and usually needs base primers as adhesive to avoid premature failure $[19,20]$.

\section{Rising Dampness in Buildings}

Flooded basements and foundations can seriously weaken the structure and foster toxic mould growth--the newest threat to residential indoor air quality. Dynamics of water table movements are slow and seasonal. If basement leaks show up after a heavy rainfall or snowmelt, the cause is far easier to be noticed for repair. The exterior areas of basement walls must be coated with a high-grade waterproofing system since old fashioned paint on black mastic is not sustainable and fails too often.

Application of a variety of vertical membrane technologies prove promising to overcome difficult ground conditions to guarantee sustainable waterproofing of the structure for the building's lifetime. Water creates such high pressures that sealing cracks will not prevent water from leaking into the house if the soil around the house is saturated. It is important to seal concrete block walls on the outside and the inner surface of block walls need to be sealed with paint or waterproofing material to retard capillary action and help prevent radon entry. The common liquid injection is time consuming as each hole needed to be injected for several minutes in order for the correct amount of fluid to be injected.

\section{Conclusion}

This paper highlighted a variety of scenarios where migration of water (and fluids) needs to be appropriate remedied to rectify unsatisfactory hydraulic barrier problems. The sustainable effectiveness of the barrier system must be evaluated, (be it with appropriate and unconventional test methods), against its interaction with the onsite environment. Short term, conventional but unrealistic testing methods need to be carefully evaluated.

\section{References}

[1] World Health Organization (WHO), Guidelines for Indoor air Quality: Dampness and Mould, (2009) 
[2] V. Novotny and P. Brown, Cities of the future: towards integrated sustainable water and landscape management, London, IWA Publishing, (2007)

[3] N. Ghafari, Corrosion control in underground concrete structures using a double waterproofing shield system (DWS), Int. J. of Mining Sci. and Tech., 23, 603-611, (2013)

[4] D.C. Wijeyesekera, K. O'Connor and D.E. Salmon, Design \& performance of a compacted clay barrier through a landfill, Engineering Geology, Special issue on Geoenvironmental Engineering, 60(1-4), 295-306, (2001)

[5] Building Construction Authority, Singapore, Design of external walls, (2014), Retrieved on August 15, 2014 from http://www.bca.gov.sg,

[6] K.A.M. Kamar, Z.A. Hamid, M.K. Ghani and A.H. Rahim, Industrial Building Systems: Current shortcomings and the vital role of $R \& D .2^{\text {nd }}$ Quarter Master Building Publication, (2007)

[7] BS 8102: 2009, Code of Preactice for protection of below ground structures against water from the ground, British Standards Institution, (2009)

[8] Images for Leaking Thatched Roofs , 2016), Retrieved on October 1, 2016 from http:// www.morganasphalte.co.uk

[9] Quality Roof Leakage Repairs, (2016), Retrieved on October 1, 2016 from http://binawaterproof.com/workingsecene.html

[10]R. Talib, D. Boyd, S. Hayhow, A.A. Ghafar and M. Suleiman, Investigating effective waterproofing materials in preventing roof leaking; initial comparative study: Malaysia, U.K. Science Direct Procedia Manufacturing, 2,419-427, (2015)

[11] S.U. Al-Dulaijan, M. Maslehuddin, M.M. Al-Zahrani, A.M. Sharif, E.A. Al-Juraifani, and S.H. Al-Idi, Performance evaluation of resin based surface coatings. In: Deterioration and Repair of Reinforced Concrete in the Arabian Gulf, Proc. of 6th ACI Int. Conf., Bahrain, 345-62, (2000)

[12] S.U. Al-Dulaijan, M. Maslehuddin, M.M. Al-Zahrani, A.M. Sharif, E.A. Al-Juraifani, S.H. Al-Idi and M. Al-Mehthel, Performance evaluation of cement-based surface coatings. In: Repair, Rehabilitation, and Maintenance of Concrete Structures, and Innovations in Design and Construction, Proc. of Fourth ACI Int. Conf., SP-193-20, Seoul, Korea, 321-35, (2000)

[13] American Society for Testing and Materials. ASTM C1202-91, Standard test method for electrical indication of concrete ability to resist chloride ion penetration. ASTM Standards, vol. 4.02, Philadelphia, (1991).

[14]D.W. Pfeiffer and M.J. Scali, Concrete sealing for protection of bridge structures. National Cooperative Highway Research Program (NCHRP 244), Transportation Research board, Washington DC,( December , 1981)

[15]ASTM C642A. American Society for Testing and Materials. ASTM C642-92, Standard test method for specific gravity, absorption, and voids in hardened concrete. vol. 4.08, ASTM Standards, , Philadelphia, (1992).

[16]S.K. Lachimpandi, J.J. Pereira, M.R. Taha and M. Mokhtar, Construction Waste Minimisation comparing Conventional and Precast Construction (Mixed System and IBS) methods in High Rise Buildings: A Malaysian Case Study, Resources, Conservation and Recycling, 68, 96-1-3, (2012)

[17]NPCCA, National Precast Concrete Association Australia, Precast Concrete Hand Book, (2012)

[18] SIKA Malaysia, Technical Brochures, (2010-2014) 
[19]CPPCI, Canadian Precast-Prestressed Concrete Institute, Architectural Precast Concrete Sealant Joint Guide, (2010)

[20]N.A. Abd Rahman, Z.M. Zainordin, S. Ahmad and N. Mahat, Maximization of IBS Elements at Wet Areas in solving Leaking Problems and Promoting Better Quality Control, Procedia Social and Behavioral Sciences, 202, 424-435, (2015) 